\title{
Front Matter: Volume 7268
}

, "Front Matter: Volume 7268," Proc. SPIE 7268, Smart Structures, Devices, and Systems IV, 726801 (21 January 2009); doi: 10.1117/12.823565

SPIE Event: SPIE Smart Materials, Nano- and Micro-Smart Systems, 2008, SPIE. Melbourne, Australia 


\title{
PROCEEDINGS OF SPIE
}

\section{Smart Structures, Devices, and Systems IV}

\author{
Said Fares Al-Sarawi \\ Vijay K. Varadan \\ Neil Weste \\ Kourosh Kalantar-Zadeh \\ Editors \\ 10-12 December 2008 \\ Melbourne, Australia \\ Sponsored by \\ SPIE \\ Cosponsored by \\ RMIT University (Australia) \\ Published by \\ SPIE
}

Volume 7268 
The papers included in this volume were part of the technical conference cited on the cover and title page. Papers were selected and subject to review by the editors and conference program committee. Some conference presentations may not be available for publication. The papers published in these proceedings reflect the work and thoughts of the authors and are published herein as submitted. The publisher is not responsible for the validity of the information or for any outcomes resulting from reliance thereon.

Please use the following format to cite material from this book:

Author(s), "Title of Paper," in Smart Structures, Devices, and Systems IV, edited by Said Fares Al-Sarawi, Vijay K. Varadan, Neil Weste, Kourosh Kalantar-Zadeh, Proceedings of SPIE Vol. 7268 (SPIE, Bellingham, WA, 2008) Article CID Number.

ISSN 0277-786X

ISBN 9780819475206

Published by

SPIE

P.O. Box 10, Bellingham, Washington 98227-0010 USA

Telephone +1 3606763290 (Pacific Time) · Fax +1 3606471445

SPIE.org

Copyright (C) 2008, Society of Photo-Optical Instrumentation Engineers

Copying of material in this book for internal or personal use, or for the internal or personal use of specific clients, beyond the fair use provisions granted by the U.S. Copyright Law is authorized by SPIE subject to payment of copying fees. The Transactional Reporting Service base fee for this volume is $\$ 18.00$ per article (or portion thereof), which should be paid directly to the Copyright Clearance Center (CCC), 222 Rosewood Drive, Danvers, MA 01923. Payment may also be made electronically through CCC Online at copyright.com. Other copying for republication, resale, advertising or promotion, or any form of systematic or multiple reproduction of any material in this book is prohibited except with permission in writing from the publisher. The CCC fee code is 0277-786X/08/\$18.00.

Printed in the United States of America.

Publication of record for individual papers is online in the SPIE Digital Library.

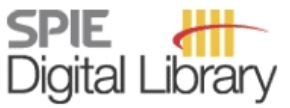

SPIEDigitalLibrary.org

Paper Numbering: Proceedings of SPIE follow an e-First publication model, with papers published first online and then in print and on CD-ROM. Papers are published as they are submitted and meet publication criteria. A unique, consistent, permanent citation identifier (CID) number is assigned to each article at the time of the first publication. Utilization of CIDs allows articles to be fully citable as soon they are published online, and connects the same identifier to all online, print, and electronic versions of the publication. SPIE uses a six-digit CID article numbering system in which:

- The first four digits correspond to the SPIE volume number.

- The last two digits indicate publication order within the volume using a Base 36 numbering system employing both numerals and letters. These two-number sets start with 00, 01, 02, 03, 04, $05,06,07,08,09,0 A, 0 B \ldots 0 Z$, followed by 10-1Z, 20-2Z, etc.

The CID number appears on each page of the manuscript. The complete citation is used on the first page, and an abbreviated version on subsequent pages. Numbers in the index correspond to the last two digits of the six-digit CID number. 


\section{Contents}

ix Conference Committee

xi Symposium Sponsor

\section{SESSION 1 ACTUATORS I}

726802 Fabrication and estimation of electromagnetic type microactuators with microcoil [7268-01]

D. Noda, M. Setomoto, Y. Kobayashi, T. Hattori, Univ. of Hyogo (Japan)

\section{SESSION 2 ACTUATORS II}

726804 A novel multi-actuation CMOS RF MEMS switch [7268-04]

C.-I. Lee, C.-H. Ko, T.-C. Huang, Industrial Technology Research Institute (Taiwan)

726805 Effective diaphragm area of spring-supported capacitive MEMS microphone designs [7268-05]

N. Mohamad, P. lovenitti, Swinburne Univ. of Technology (Australia); T. Vinay, RMIT Univ. (Australia)

726806 Stiffness characterisation of microcantilevers based on conducting polymers [7268-06] G. Alici, M. J. Higgins, Univ. of Wollongong (Australia)

726808 Optimizing efficiency of energy harvesting by macro-fiber composites [7268-08] L. Tang, Y. Yang, Nanyang Technological Univ. (Singapore); H. Li, Shanghai Jiao Tong Univ. (China)

\section{SESSION 3 ANALOG AND DIGITAL}

726809 Memory rich applications for 3D integration (Invited Paper) [7268-09]

P. D. Franzon, S. Lipa, J. Oh, T. Thorolfsson, R. Davis, North Carolina State Univ. (United States)

7268 OA Comparison of various order TDTL frequency synthesizers [7268-10]

M. Al-Qutayri, S. Al-Araji, Khalifa Univ. of Science, Technology and Research (United Arab Emirates); A. Al-Humaindan, Etisalat Corp. (United Arab Emirates); S. Al-Balooshi, Khalifa Univ. of Science, Technology and Research (United Arab Emirates)

7268 OC Ultra-high density standard cell library using multi-height cell structure [7268-12] S.-H. Baek, Samsung Electronics (Korea, Republic of) and Sungkyunkwan Univ. (Korea, Republic of); H.-Y. Kim, Y.-K. Lee, Samsung Electronics (Korea, Republic of); D.-Y. Jin, S.-C. Park, J.-D. Cho, Sungkyunkwan Univ. (Korea, Republic of)

7268 OD High-performance bridge-style full adder structure [7268-13] O. Kavehei, S. F. Al-Sarawi, D. Abbott, The Univ. of Adelaide (Australia); K. Navi, Shahid Beheshti Univ. (Iran, Islamic Republic of) 
7268 OE Performance characteristics of a nanoscale double-gate reconfigurable array [7268-14]

P. Beckett, RMIT Univ. (Australia)

7268 OF Defect tolerant prefix adder design [7268-15]

R. Moric, B. J. Phillips, M. J. Liebelt, The Univ. of Adelaide (Australia)

SESSION 4 FIBERS

7268 OG One-step fabrication of micro-deflector and optical waveguide by femtosecond two-photon polymerization [7268-16]

C.-Y. Tai, J.-W. Tseng, National Central Univ. (Taiwan)

$7268 \mathrm{Ol} \quad$ Optical link by using optical wiring method for reducing EMI [7268-18]

I.-K. Cho, J.-H. Kwon, S.-W. Choi, A. Bondarik, J.-H. Yun, C.-J. Kim, Electronics and

Telecommunications Research Institute (Korea, Republic of); S.-B. Ahn, Hongik Univ. (Korea, Republic of); M.-Y. Jeong, Pusan National Univ. (Korea, Republic of); H. H. Park, Information and Communications Univ. (Korea, Republic of)

\section{SESSION $5 \quad$ GAS SENSORS}

7268 OK Pt/anodized $\mathrm{TiO}_{2}$ /SiC-based MOS device for hydrocarbon sensing [7268-20]

M. Shafiei, A. Z. Sadek, J. YU, R. Arsat, K. Kalantar-Zadeh, RMIT Univ. (Australia); X. F. YU, Shanghai Institute of Ceramics (China); J. G. Partridge, W. B. Wlodarski, RMIT Univ. (Australia)

$7268 \mathrm{OL} \quad \mathrm{Pt} / \mathrm{ZnO} / \mathrm{SiC}$ thin film for hydrogen gas sensing [7268-22]

J. C. W. YU, M. Shafiei, C. Ling, W. B. Wlodarski, K. Kalantar-Zadeh, RMIT Univ. (Australia)

$72680 \mathrm{M}$ A hydrogen gas sensor fabricated from polythiophene nanofibers deposited on a $36^{\circ} \mathrm{YX}$ $\mathrm{LiTaO}_{3}$ layered surface acoustic wave transducer [7268-23]

L. Al-Mashat, RMIT Univ. (Australia); H. D. Tran, R. B. Kaner, Univ. of California, Los Angeles

(United States); R. Arsat, K. Kalantar-Zadeh, W. Wlodarski, RMIT Univ. (Australia)

\section{SESSION 6 SENSORS}

$72680 \mathrm{~N} \quad$ Real-time integrity monitoring of composite laminates with magnetostrictive sensory layer [7268-24]

A. Kumar, Harcourt Butler Technological Institute (India); B. Bhattacharya, Indian Institute of Technology, Kanpur (India)

$72680 Q \quad$ MEMS accelerometer-driven fuel-control system for automobile applications [7268-27] R. Mukhiya, S. Gangopadhyay, B. Guha, T. K. Bhattacharyya, Indian Institute of Technology, Kharagpur (India); A. Boni, Univ. of Trento (Italy); M. Zen, FBK-irst (Italy); S. K. Lahiri, Indian Institute of Technology, Kharagpur (India)

7268 OR Element count reduction of a thermo-resistive hot-wire anemometer [7268-28]

R. J. Adamec, Griffith Univ. (Australia) 
7268 OS Preconcentrator-based sensor $\mu$-system for low-level benzene detection [7268-29] P. Ivanov, I. Gràcia, National Ctr. of Microelectronics (Spain); F. Blanco, Univ. Rovira i Virgili (Spain); J.-P. Raskin, Univ. Catholique de Louvain (Belgium); R. Cumeras, N. Sabaté, National Ctr. of Microelectronics (Spain); X. Vilanova, X. Correig, Univ. Rovira i Virgili (Spain); L. Fonseca, E. Figueras, J. Santander, C. Cané, National Ctr. of Microelectronics (Spain)

7268 OT A smart resonating micro-cantilever in MEMS gas sensor: improved design [7268-30] J. H. Zhao, S. J. Yu, K. Li, Q. Zhou, Z. You, Tsinghua Univ. (China)

\section{SESSION 7 DEVICES}

7268 OU Self-aligned double-gate (DG) nanoscale vertical MOSFETs with reduced parasitic capacitance [7268-31]

R. Ismail, Univ. Teknologi Malaysia (Malaysia); I. Saad, Univ. Malaysia Sabah (Malaysia)

$7268 \mathrm{OV}$ Theoretical analysis of free-space optical coupling loss in a multilevel optical system [7268-32]

M. A. Al Hafiz, M. R. Mackenzie, C. Y. Kwok, Univ. of New South Wales (Australia)

\section{SESSION 8 RF AND THZ}

7268 0X Practical considerations for high-frequency inductive links [7268-35]

A. N. Laskovski, M. R. Yuce, T. N. Dissanayake, Univ. of Newcastle (Australia)

\section{SESSION 9 STRUCTURAL HEALTH MONITORING}

726810 Power harvesting and management from vibrations: a multi-source strategy simulation for aircraft structure health monitoring [7268-39]

H. Durou, C. Rossi, M. Brunet, LAAS-CNRS, Univ. de Toulouse (France); C. Vanhecke, Thalès Alenia Space (France); N. Bailly, G. Ardila, L. Ourak, A. Ramond, LAAS-CNRS, Univ. de Toulouse (France); P. Simon, P.-L. Taberna, Univ. de Toulouse, UMR 5085 CNRS, UPS, INPT (France)

726811 Monitoring system for the displacement of the moveable end of a bridge using optical fiber sensors [7268-40]

K.-T. Park, Korea Institute of Construction Technology (Korea, Republic of)

726812 Development of automatic blood extraction device with a micro-needle for blood-sugar level measurement [7268-41]

K. Kawanaka, Y. Uetsuji, Osaka Institute of Technology (Japan); K. Tsuchiya, Tokai Univ. (Japan); E. Nakamachi, Doshisha Univ. (Japan)

726813 Application of PZT sensors for detection of damage severity and location in concrete [7268-42]

B. Sabet Divsholi, Y. Yang, Nanyang Technological Univ. (Singapore)

726814 Fibre Bragg grating acoustic emissions and transmission sensor in carbon fibre composites [7268-43]

G. Wild, S. Hinckley, Edith Cowan Univ. (Australia) 
726816 Fabrication of a gas flow device consisting of micro-jet pump and flow sensor [7268-21]

K. Tanaka, V. T. Dau, T. Otake, T. X. Dinh, S. Sugiyama, Ritsumeikan Univ. (Japan)

726817 Research on real-time object labeling methods [7268-45]

Z. Chen, J. Cai, Q. Zhang, Z. Xu, Institute of Optics and Electronics (China)

726818 Research and design of a novel system of optical image processing [7268-46]

L. Liu, H. YU, Z. Zhao, Y. Chen, P. Li, Nanjing Univ. of Aeronautics and Astronautics (China)

7268 1A A measurement study of cognitive radio spectrum sensing methods [7268-48]

B. Jamali, E. Kurniawan, M. Bazghaleh, The Univ. of Adelaide (Australia)

7268 1B A passive harmonic reradiator tag for animal tracking [7268-49]

B. Jamali, The Univ. of Adelaide (Australia)

7268 1D A wireless batteryless piezoresistive pressure sensing system [7268-51]

L.-C. Hsu, W.-D. Huang, The Univ. of Texas at Arlington (United States); S.-J. Tang, Univ. of Texas - Southwestern Medical Ctr. (United States); J. C. Chiao, The Univ. of Texas at Arlington (United States)

7268 IE A patch antenna-based strain sensor for structural health monitoring [7268-52]

U. Tata, H. Huang, S. Deb, J. Wang, J.-C. Chiao, The Univ. of Texas at Arlington (United States)

7268 IF Characterization techniques for NEMS/MEMS devices [7268-53]

C.-L. Wong, M. Palaniapan, National Univ. of Singapore (Singapore)

7268 IG Research on signal processing system in smart clothes based on FBG [7268-54]

C. Zhang, C. Miao, H. Song, H. Li, B. Shi, F. XU, Tianjin Polytechnic Univ. (China)

$7268 \mathrm{1H}$ An efficient scan diagnosis methodology according to scan failure mode for yield enhancement [7268-55]

J.-T. Kim, Samsung Electronics (Korea, Republic of) and Sungkyunkwan Univ. (Korea, Republic of); N.-S. Seo, G.-G. Oh, D.-G. Kim, K.-T. Lee, C.-Y. Choi, Samsung Electronics (Korea, Republic of); I. Kim, H. B. Min, Sungkyunkwan Univ. (Korea, Republic of)

7268 iJ Optical switching of a proposed stationary optical delay line for OCT [7268-57] P. Jansz, G. Wild, S. Hinckley, Edith Cowan Univ. (Australia)

7268 IK Fluorescence-based distributed chemical sensing for structural health monitoring [7268-58] E. I. Sinchenko, W. E. K. Gibbs, P. R. Stoddart, Swinburne Univ. of Technology (Australia)

7268 IN CRISP: a flexible integrated development platform for RFID systems [7268-61]

B. Jamali, The Univ. of Adelaide (Australia)

$72681 Q \quad$ A numerical technique for solving Schrödinger's Equation in molecular electronic applications [7268-64]

A. J. Smith, A. R. Baghai-Wadji, RMIT Univ. (Australia) 
7268 IR A $0.68-\mathrm{dB} N \mathrm{NF}, 1.1 \mathrm{GHz}$-band low noise amplifier for square kilometer array application [7268-65]

K. Shah, H. P. Le, J. Singh, J. Devlin, La Trobe Univ. (Australia)

7268 1T Extension of high-illumination level dynamic range for CMOS active pixel sensors [7268-67] M.-W. Seo, S.-H. Seo, J.-K. Shin, Kyungpook National Univ. (Korea, Republic of)

7268 IV Exact locating of sub-surface microelectronic structures using scanning thermal-wave microscopy [7268-69]

J. Chung, K. Kim, G. Hwang, O. Kwon, Korea Univ. (Korea, Republic of); J. S. Lee, Seoul National Univ. (Korea, Republic of); S. Park, Hongik Univ. (Korea, Republic of); Y. K. Choi, Chung-Ang Univ. (Korea, Republic of)

7268 IY Quantum-yield computation for photo-initiators based on photometric analysis [7268-72] P. Li, Z. Zhao, X. Hong, H. YU, Nanjing Univ. of Aeronautics and Astronautics (China)

726812 Survey of terahertz metamaterial devices [7268-73]

W. Withayachumnankul, The Univ. of Adelaide (Australia) and King Mongkut's Institute of Technology Ladkrabang (Thailand); D. Abbott, The Univ. of Adelaide (Australia)

Author Index 
Downloaded From: https://www.spiedigitallibrary.org/conference-proceedings-of-spie on 26 Apr 2023

Terms of Use: https://www.spiedigitallibrary.org/terms-of-use 


\title{
Conference Committee
}

\author{
Symposium Chairs
}

Arnan Mitchell, RMIT University (Australia)

Min Gu, Swinburne University of Technology (Australia)

Conference Chair

Said Fares Al-Sarawi, The University of Adelaide (Australia)

Conference Cochairs

Vijay K. Varadan, University of Arkansas (United States)

Neil Weste, NHEW R\&D Pty Ltd. (Australia)

Kourosh Kalantar-Zadeh, RMIT University (Australia)

Program Committee

Derek Abbott, The University of Adelaide (Australia)

Kamal E. Alameh, Edith Cowan University (Australia)

Mahmoud A. Al-Qutayri, Khalifa University for Science, Technology and Research (United Arab Emirates)

Robert J. Clarke, RADLogic Pty Ltd. (Australia)

Sorin D. Cotofana, Technische Universiteit Delft (Netherlands)

Bernard Courtois, Circuits Multi-Projets (France)

Paul D. Franzon, North Carolina State University (United States)

Kamran Ghorbani, RMIT University (Australia)

Kenneth J. Grant, Defence Science and Technology Organisation (Australia)

Hedley J. Hansen, Defence Science and Technology Organisation (Australia)

Abbas Z. Kouzani, Deakin University (Australia)

Kevin C. Liddiard, Electro-optic Sensor Design (Australia)

Michael Liebelt, The University of Adelaide (Australia)

Warren Marwood, Defence Science and Technology Organisation (Australia)

Alireza Moini, Silverbrook Research Pty Ltd. (Australia)

Brian W. H. Ng, The University of Adelaide (Australia)

Saeid Nooshabadi, University of New South Wales (Australia)

Braden J. Phillips, The University of Adelaide (Australia)

Justin Spangaro, Spangaro Systems (Australia)

David V. Thiel, Griffith University (Australia)

Ajay Tikka, The Univ. of Adelaide (Australia)

Mehmet R. Yuce, The University of Newcastle (Australia) 


\author{
Session Chairs \\ 1 Actuators 1 \\ Kevin C. Liddiard, Electro-optic Sensor Design (Australia) \\ 2 Actuators II \\ Said Fares AI-Sarawi, The University of Adelaide (Australia) \\ 3 Analog and Digital \\ Michael Liebelt, The University of Adelaide (Australia) \\ $4 \quad$ Fibers \\ Mahmoud A. Al-Qutayri, Khalifa University for Science, Technology and \\ Research (United Arab Emirates) \\ 5 Gas Sensors \\ Brian W. H. Ng, The University of Adelaide (Australia) \\ 6 Sensors \\ Kourosh Kalantar-Zadeh, RMIT University (Australia) \\ 7 Devices \\ Braden J. Phillips, The University of Adelaide (Australia) \\ $8 \quad \mathrm{RF}$ and $\mathrm{THz}$ \\ Kamran Ghorbani, RMIT University (Australia) \\ 9 Structural Health Monitoring \\ Said Fares Al-Sarawi, The University of Adelaide (Australia)
}


Cosponsored by:

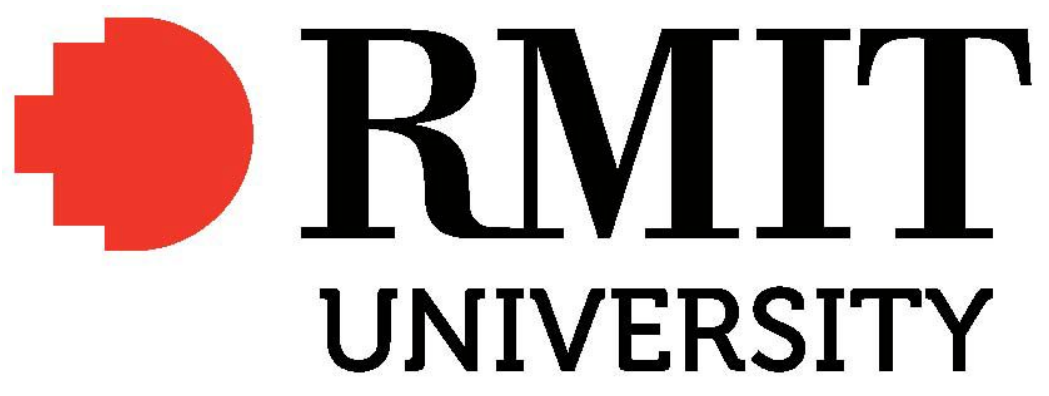


Downloaded From: https://www.spiedigitallibrary.org/conference-proceedings-of-spie on 26 Apr 2023

Terms of Use: https://www.spiedigitallibrary.org/terms-of-use 